\title{
Comparison of extensive or semi-intensive feeding for Anatolian water buffalo
}

\author{
Taskin Degirmencioglu ${ }^{1 *}$, Halil Unal ${ }^{2}$, Hasan Kuraloglu² \\ ${ }^{1}$ Department of Feed Technology and Animal Nutrition, Uludag University, Karacabey Vocational School, Republic of Turkiye; ${ }^{2}$ Department of \\ Biosystems Engineering, Uludag University, Faculty of Agriculture, Republic of Turkiye
}

\section{A B S TR A C T}

This study was carried out to determine the effects of extensive or semi-intensive feeding on dry matter intake and milk composition in Anatolian water buffalo. Buffaloes were taken into trial in the $1^{\text {st }} 2^{\text {nd }}$ months of their lactation. The buffaloes were divided into 2 groups, an extensive group (A) and a semi-intensive group (B) each group consisting of 12 buffaloes. Compared to the A group, the B group consumed more total dry matter $\left(\mathrm{P}<0.05 ; 13.17\right.$ vs. $\left.11.12 \mathrm{~kg} \mathrm{day}^{-1}\right)$ and produced more milk day ${ }^{-1}\left(\mathrm{P}<0.05 ; 7.34 \mathrm{vs}^{2} 4.42 \mathrm{~kg} \mathrm{day}^{-1}\right)$. In the milk samples which were taken from the group $A$ had higher $(P<0.05)$ milk fat percentage than group $B$ (milk fat $=8.03$ and $5.80 \%$, respectively). The somatic cell count (SCC) $\left(44.7\right.$ and $\left.60.3 \times \log 10 \mathrm{~mL}^{-1}\right)$, SNF $(10.29$ and $10.18 \%)$ and protein percentages of milk (4.95 and $4.96 \%$ ) were similar for both groups.

Keywords: Extensive or semi-intensive feeding system; Anatolian water buffalo

\section{INTRODUCTION}

The Turkish name for the Anatolian water buffalo (AWB) breeders is Camiz. AWB are mostly bred in the Central Black Sea, Marmara (Thrace) and Western Central Anatolia regions of Turkey (Atasever and Erdem, 2008). On Nowadays, their numbers have been decreasing because of reasons such as drying of rivers, having low milk yield and increasing of demand for dairy cow. The number of AWB in Turkey was estimated to be 121.826 in 2014; this corresponds to 0.85 percent of the total cattle population of the country (TUIK, 2014). Total milk production in that year was 18498 630 tons, 1113130 tons being sheep milk, 463394 tons goat milk, 16867419 tons cow milk and 54687 tons buffalo milk (TUIK, 2014). Milk obtained from buffaloes is partly used locally for the nutritional needs of the owners, and excess milk is sold for yogurt and kaymag making. Nutrition of buffalo in Turkey depends traditionally on grazing of natural pastures. The feeding systems by (Devendra, 1981) divided into following systems: Extensive system, semi-intensive system and very intensive system. In village system which known as extensive system, bufalloes herds obtain their feeding by grazing along water sources. Borghese, (2005) reported that in Turkey, buffaloes were predominantly fed on grazing and wheat bran during summer and stems of maize concentrates during winter time. In grazing animals in extensive rearing can face nutritional unbalance during summer time. They may show decreased milk production (Fedele et al., 1993). Previous studies have reported that semi-intensive feeding improved milk yield in dairy goats (Fedele et al., 1993; Morge 2000; Claps et al., 2003) and dairy ewes (Pulina et al., 2006). In another study, Terzano et al., (2007) observed that extensive feeding systems decreased significantly the body linear measurements of buffaloes. In contrast no differences was found in milk yield and milk composition in other study (Faruque and Hossain; 2007). Degirmencioglu et al., (2013) reported that daily milk yield of buffaloes were about $7.1 \mathrm{~kg} \mathrm{~d}^{-1}$ in the semi-intensive farm.

Milk yield can increase by improving feeding strategy of buffaloes living under village conditions. According to the literature reviews there has not been any published paper on feeding method for AWB.

\footnotetext{
*Corresponding author:

Dr Taskin Degirmencioglu, Department of Feed Technology and Animal Nutrition, Uludag University, Karacabey Vocational School, 16700 Karacabey, Bursa, Republic of Turkiye. Tel. +90 224 6768780, Fax: +902246765562, E-mail: taskin@uludag.edu.tr
} 
The aim of the present study was to investigate the effects of semi intensive or extensive feeding on performance and milk yield for AWB.

\section{MATERIALS AND METHODS}

This experiment was conducted at Karaoglan Village located of Mustafakemalpasa in Bursa. The experiment was carried out in 2014 with 12 buffaloes from local family farms. Buffaloes in the experiment were 5 and 6 years old were randomly divided in two groups with equal live body weight, days in milk and milk yield (Table 1). The total experiment lasted 30 days, in which the first two weeks were preliminary for adaptation and in two weeks were collected data for statistical analysis. The animals from first group (control (A) receives roughage and second group (B) control ration plus concentrate feed mixture-(CFM) were fed $700 \mathrm{~g} \mathrm{CFM}$ per liter milk (191.3 g CP kg DM${ }^{-1}$ and 2861 ME (Kcal kg DM-1, Table 2).

The offered feeds were assessed to cover the maintenance and production requirements for each animal NRC (2001) recommendations for dairy cattle. On Group A, buffaloes were fed on ad libitum pasture, corn silage $\left(25 \mathrm{~kg} \mathrm{~d}^{-1}\right)$, alfalfa hay $\left(3 \mathrm{~kg} \mathrm{~d}^{-1}\right)$ and $0.40 \mathrm{~kg}$ of barley hay without CFM. The experimental diet consisted of CFM: roughage (1:3.5 on DM basis). The CFM for group B was offered individually once a day at milking period. For both groups while alfalfa was offered at 6:30 a.m. silage was offered once a day 7:30 p.m. in group level.

The buffaloes had ad libitum access to water and pasture. Dry matter intake was measured at the end of the sample collection period by weighing the offered diet and refusals from the previous day. Pasture consumption was not determined because of free pasture. The animals were milked twice a day at 6:30 a.m. and 7:30 p.m. Milk yield was measured daily. Milk samples were collected from each buffalo at the end of the sample collection period. The milk from each buffalo was individually sampled at the delivery site of the firms in the morning. All the samples in a $250 \mathrm{ml}$ of tubes were stored at $5 \pm 1{ }^{\circ} \mathrm{C}$ before analysis. The fat-corrected milk yield (4\%) was calculated according to Kumlu (1999). The dry matter, organic matter, crude protein, crude fat and ash contents of the diets were estimated according to AOAC (1990). Neutral detergent fibre (NDF) and acid detergent fibre (ADF) were determined using the methods outlined by Robertson and Van Soest (1981). The metabolizable energy value of feeds was calculated from chemical analyses of feed based on the computer software of the National Research Council (NRC) (NRC, 2001). Solids non-fat (SNF), fat, protein and lactose contents of milk were determined using a Milcosan FT-120. The somatic cell count (SCC) was
Table 1: The basic information on the examined buffaloes (mean \pm SE)

\begin{tabular}{lccc}
\hline Groups & $\begin{array}{c}\text { Body } \\
\text { weight }(\mathbf{k g})\end{array}$ & $\begin{array}{c}\text { Days in } \\
\text { milk }\end{array}$ & $\begin{array}{c}\text { Milk yield } \\
(\mathbf{k g} / \mathbf{d})\end{array}$ \\
\hline Control group (A) & $521.50 \pm 5.50$ & $35.33 \pm 0.91$ & $4.37 \pm 0.18$ \\
Semi-intensive group (B) & $526.33 \pm 6.71$ & $37.92 \pm 1.94$ & $4.48 \pm 0.17$ \\
Level of significance & $\mathrm{NS}$ & $\mathrm{NS}$ & $\mathrm{NS}$ \\
\hline NS: Non significant. Group's average of body condition score (BCS) is 2.5-3
\end{tabular}

Table 2: Ingredient composition and chemical analysis of the experimental diet

\begin{tabular}{|c|c|c|c|c|}
\hline \multirow[t]{2}{*}{ Ingredient $\left(\mathbf{g ~ k g}^{-1}\right)$} & \multirow{2}{*}{$\begin{array}{c}\text { Diet } \\
\text { Group B }\end{array}$} & \multicolumn{2}{|c|}{$\begin{array}{c}\text { Roughages for } \\
\text { group A and group B }\end{array}$} & \multirow[t]{2}{*}{$\begin{array}{l}\text { Corn } \\
\text { silage }\end{array}$} \\
\hline & & Alfa hay & Barley hay & \\
\hline Barley & 310 & - & - & - \\
\hline Wheat & 320 & - & - & - \\
\hline Sunflower meal & 350 & - & - & - \\
\hline Marble powder & 10 & - & - & - \\
\hline Salt & 7.5 & - & - & - \\
\hline Vitamin+minerals $^{1}$ & 2.5 & - & - & - \\
\hline Total & 1000 & - & - & - \\
\hline \multicolumn{5}{|c|}{ Nutrient composition $\left(\mathrm{g} \mathrm{kg}^{-1}\right)$} \\
\hline $\mathrm{DM}^{2}$ & 887 & 904.8 & 933.1 & 342.3 \\
\hline OM & 855.7 & 815.5 & 869.1 & 288 \\
\hline $\mathrm{CP}$ & 191.3 & 133.0 & 28.3 & 73.1 \\
\hline EE & 19.5 & 15.5 & 10.5 & 25.6 \\
\hline CELL & 90.2 & 334.6 & 405.5 & 209.7 \\
\hline $\mathrm{CA}$ & 31.3 & 89.3 & 64.0 & 54.3 \\
\hline NFE & 554.7 & 332.4 & 424.8 & - \\
\hline Starch & 416.3 & 21.8 & 6.8 & 240.6 \\
\hline NDF & 192.0 & 509.9 & 741.0 & 472.8 \\
\hline ADF & 136.7 & 463.9 & 604.1 & 338.9 \\
\hline$A D L$ & 36.8 & 113.5 & 109.0 & 69.7 \\
\hline $\mathrm{ME}(\mathrm{k} \mathrm{cal} / \mathrm{kg} \mathrm{DM})^{3}$ & 2861 & 1801 & 1650 & 769.72 \\
\hline
\end{tabular}

${ }^{1}$ Trace minerals and vitamins (per kg): $50.000 \mathrm{mg}$ Niacin; $150 \mathrm{mg} \mathrm{Co;} 800 \mathrm{mg}$ lyot; 150 mg Se; 50.000 mg Mn; 50.000 mg Fe; Zn 50.000 mg; Cu 10.000 mg; 15.000 .000 IU Vitamin A; 3.000 .000 IU Vitamin D3;20.000 mg Vitamin E. ${ }^{2} \mathrm{DM}$ : Dry Matter; OM: Organic Mattter; CP: Crude Protein; EE: Ether Extract; CELL: Cellulose; CA: Crude Ash; NFE: Nitrogen free ext; NDF: Neutral Detergent Fibre; ADF: Acid Detergent Fibre; ME: Metabolizable Energy

determined with a somacount 150 (Bentley Instruments, chaska, USA). The means of each parameter measured in the milk yield and milk composition were tested by analysis of variance using the SPSS version15.0 Statistical Package (2006) and means were compared using t-test model described by Cochran and Cox (1957):

Yijkl- $\mu+\mathrm{Ti}+\mathrm{Pj}+\mathrm{Eijk}$, where:

Yijk - observation

$\mu$ - population mean

$\mathrm{Ti}$ - feeding (extensive and semi-intensive)

$P j-\operatorname{animals}(j=1,2,3, \ldots . .23$ or 24$)$

Eijk - residual error. 


\section{RESULTS AND DISCUSSION}

During the experimental period, the silage DM consumption was 8.23 and $5.72 \mathrm{~kg} \mathrm{day}^{-1}$ in A and B groups $(\mathrm{P}<0.05$, Table 3). The consumption in the $\mathrm{DM}$ from alfalfa hay in corresponding group was 2.61 and $4.46 \mathrm{~kg}^{\text {day }}{ }^{-1}$ $(\mathrm{P}<0.05)$. In this study, the average total dry matter intake (TDM) in group B was higher than in group A with $15.56 \%$ $(\mathrm{P}<0.05$; Table 3$)$. The balance of nutrition was also better as a result of adding concentrate feed for the rest of milk yield in group B. As shown in Table 2, daily milk yields for the groups A and B were 4.37 and $4.48 \mathrm{~kg}$ day $^{-1}$, respectively, before experiment. The semi-intensive feeding improved $(\mathrm{P}<0.01)$ milk yield by $2.92 \mathrm{~kg} \mathrm{~d}^{-1}\left(7.34 \mathrm{vs} .4 .42 \mathrm{~kg} \mathrm{~d}^{-1}\right)$ for $\mathrm{B}$ and A group, respectively after experiment. The differences between the mean milk production values of group $A$ and group B were significant $(\mathrm{P}<0.05$; Table 3$)$. The estimated regression equation for milk yield is presented in Table 4. The regression equation obtained from the data was:

$$
\begin{array}{ll}
\mathrm{Y}=-1.22+0.491 \mathrm{X}_{1}, & (\text { for group } \mathrm{A}) \text { and } \\
\mathrm{Y}=2.04+0.25 \mathrm{X}_{1}, & (\text { for group } \mathrm{B})
\end{array}
$$

where " $\mathrm{y}$ " represents the estimated milk yield and " $\mathrm{X}_{1}$ represents Total ME (kcal/kg DM) of feeds consumed, " $\mathrm{R}^{2}$ " represent the correlation degree of these relationship.

(Group A; $\mathrm{R}^{2}=0.46$ vs Group B; $\mathrm{R}^{2}=0.81$ ). The significantly greater response in milk yield to increases in Total ME level ( $\mathrm{k} \mathrm{cal} / \mathrm{kg} \mathrm{DM})$ with the semi-intensive feeding (20.950 Total ME; $\mathrm{k} \mathrm{cal} / \mathrm{kg}$ DM) compared with the extensive feeding (11.493 Total ME; $\mathrm{kcal} / \mathrm{kg} \mathrm{DM}$ ) is in accord with observations by Singh and Kumar, (2007) and Pridolova et al.,(2009). This effect on group A was probably associated with the limited availability of body reserves and reduction in energy intake because of mainly consumption based on roughage (Fedele et al., 1993; Pulina et al., 2006). Similarly Cabiddu et al., (1999) reported that the quantity of energy was important in milk production of goats. However, Faruque and Hossain (2007) have reported that the addition of $1 \mathrm{~kg}$ of concentrate mixtures does not significantly increase the milk yield in Banglades buffalo but induces a difference of $0.38 \mathrm{~kg}$ milk/animal/day between the treated (rice straw and plus concentrate mixture) and extensive (based on rice straw) groups. This effect may be attributed to giving less concentrate feed and using buffalo with 258 days of lactation (late period). In the present study, the ration contained $22 \%$ concentrate (DM basis). The mean milk yield determined on group B was $7.34 \mathrm{~kg} \mathrm{~d}^{-1}$ (Table 3 ). This value was similar to $7.10 \mathrm{~kg} \mathrm{~d}^{-1}$, the value reported by Degirmencioglu et al., (2013) and higher than $5.5 \mathrm{~kg} \mathrm{~d}^{-1}$, the value reported by Şekerden, (2011). A similar trend was also recorded for $4 \%$ fat-corrected milk ( $4 \%$ FCM).
Table 3: Effects of extensive or semi-intensive feeding on DM intake and milk composition in AWB (mean+SE)

\begin{tabular}{lccc}
\hline Parameter & $\begin{array}{c}\text { Group A } \\
\text { (extensive) }\end{array}$ & $\begin{array}{c}\text { Group B } \\
\text { (Semi-intensive) }\end{array}$ & P value \\
\hline Body-weight & $521.50 \pm 5.50$ & $526.33 \pm 6.71$ & NS \\
Silage DM intake $\left(\mathrm{kg} \mathrm{d}^{-1}\right)$ & $8.23 \pm 0.43$ & $5.72 \pm 0.29$ & $*$ \\
Alfalfa DM intake $\left(\mathrm{kg} \mathrm{d}^{-1}\right)$ & $2.61 \pm 0.11$ & $4.46 \pm 0.29$ & $*$ \\
Barley straw DM intake & $0.28 \pm 0.07$ & $0.08 \pm 0.02$ & $*$ \\
Concentrate DM intake & - & $2.90 \pm 0.23$ & - \\
Total DM intake1 & $11.12 \pm 0.40$ & $13.17 \pm 0.41$ & $*$ \\
Milk yield $\left(\mathrm{kg} \mathrm{d}^{-1}\right)$ & $4.42 \pm 0.25$ & $7.34 \pm 0.24$ & $*$ \\
4\% FCM $\left(\mathrm{kg} \mathrm{d}^{-1}\right)^{2}$ & $7.11 \pm 0.48$ & $9.31 \pm 0.34$ & $*$ \\
Fat $(\%)$ & $8.03 \pm 0.41$ & $5.80 \pm 0.19$ & $*$ \\
SNF $(\%)$ & $10.29 \pm 0.07$ & $10.18 \pm 0.05$ & $\mathrm{NS}$ \\
Protein $(\%)$ & $4.95 \pm 0.08$ & $4.96 \pm 0.15$ & $\mathrm{NS}$ \\
SCC (x log10 $\left.\mathrm{mL}^{-1}\right)$ & $44.70 \pm 9.08$ & $60.3 \pm 6.83$ & $\mathrm{NS}$ \\
\hline
\end{tabular}

${ }^{1}$ Total DM intake values for buffaloes were not added to pasture consumption. $4 \%$ FCM $=4 \%$ fat-corrected milk; SNF: Solids-not-fat; SCC: Somatic Cell Count; NS: Non significant; * $P$ value $<0.05$

Table 4: Estimated regression equations $(y=a+b x)$ for milk yield

\begin{tabular}{lccc|}
\hline $\mathbf{Y}$ (milk yield) & a (constant) & $\mathbf{X}_{\mathbf{I}}$ (total ME) & $\mathbf{R}^{2}$ \\
\hline Group A & $-1.22 \pm 1.92$ & $0.91 \pm 0.167^{*}$ & $0.46 \pm 0.67^{*}$ \\
Group B & $2.05 \pm 0.81^{*}$ & $0.25 \pm 0.039^{*}$ & $0.81 \pm 0.38^{*}$ \\
\hline
\end{tabular}

Group A, B ( $F=8.7$ and 42.73)

Yield of $4.0 \%$ FCM was increased $(\mathrm{P}<0.05)$ by $23.63 \%$ with semi-intensive feeding ( 9.31 vs. $7.11 \mathrm{~kg} \mathrm{~d}^{-1}$ for group B and group A respectively; Table 3). Milk parameters taken from two groups are shown in Table 3. The fat contents of milk were lower in group B than group A. Probably due to more milk production or less forage intake. The difference was statistically significant $(\mathrm{P}<0.05)$. In the present study, such reduction for milk fat was determined as $27.77(\%)$ in group B. Conversely, Faruque and Hossain (2007) showed that milk fat contents were statistically insignificant affected by semi-intensive feeding. The observed response of variation may be related to several factors, such as forage type, forage-to-concentrate ratio, feeding strategy, differences in individual animals and lactation length (Degirmencioglu, 2014). The semi-intensive feeding had no significant effect on the percentages of SNF, protein or SCC in milk.

\section{CONCLUSION}

In this study results show that the related table 3 has shown that semi-intensive feeding increased the milk yield, but it reduced the fat percentage in milk without affecting other milk compositions (SNF, Protein and SCC). In addition a consumption of quality roughage and an increasing of CFM according to milk yield level would be useful for buffalo farms located in Mustafakemalpasa region. There is presently a good demand for buffalo milk in the highincome cities of Turkey. Therefore, increasing of buffalo milk with semi-intensive feeding is importance to maintain 
life of Turkish buffalo in the future. As a future work, the other feeding methods maybe investigated for the AWB and also the economical side can be researched.

\section{Author contributions}

T. D. designed and conducted most of experiments, statistical analysing the result and writing manuscription. H. U. and H. K. were involved to choosing sample of animals and collecting data.

\section{REFERENCES}

AOAC. 1990. Official Methods of Analysis. $15^{\text {th }}$ ed. Assoc Off Anal Chem, Arlington, VA.

Atasever, S. and H. Erdem. 2008. Water buffalo raising and its future in Turkey. OMÜ J. Agric. Fac. 23: 59-64.

Borghese, A. 2005. Buffalo production and research. In: A. Borghese (Ed.),, Technical Series 67 Food and Agriculture Organization, Rome, Italy.

Cochran, W. G. and G. M. Cox. 1957. In Experimental Designs. $2^{\text {nd }}$ ed. John Wiley and Sons, New York, N.Y., p. 536.

Cabbidu, A, A. Branca, M. Decandia, A. Pes, P. M. Santucci, F. Masoero and L. Calamari. 1999. Relationship between body condition score, metabolic profile, milk yield and milk composition in goats browsing a Mediterranean Shrubland. Livest. Prod. Sci. 61: 267-273.

Claps, S., R. Rubino, V. Fedele, G. Morone, Di and A. Trana. 2003. Effect of concentrate supplementation on milk production, chemical features and milk volatile compounds in grazing goats. In: FAO-CIHEAM Seminar on Sustainable Grazing, Nutritional Utilization and Quality of Sheep and Goat Products, Grenada (Sp.), 2-4 October 2003, Session 2, p. 43.

Devendra, C. 1981. Feeding system for goats in the humid tropics. Int. Symp. On Nutrition and Systems of Goat feeding, 12-15 1981, Tours, France, Vol. 1., p. 395-410.

Degirmencioglu, T., T. Ozcan, S. Ozbilgin and S. Senturklu. 2013. Effects of yeast culture addition (Saccharomyces cerevisiae) to Anatolian water buffalo diets on milk composition and somatic cell count. Mljekarstvo. 63: 42-48.

Degirmencioglu, T. 2014. Using humic acid in diets for dairy goats.
Anim. Sci Pap. Rep. 32: 25-32.

Kumlu, S. 1999. Animal Breeding in Akdeniz Univ. Agr. Fak, Zootecni Antalya., p. 66.

Faruque, M. O. and M. I. Hossain. 2007. The effect of feed supplement on the yield and composition of buffalo milk. Ital. J. Anim. Sci. 6: 488-490.

Fedele, D., M. Pizzillo, S. Claps, P. Morand-Fehr and R. Rubino. 1993. Grazing behaviour and diet selection of goats on native pasture in Southern Italy. Small Rumin. Res. 11: 305-322.

Morge, F. 2000. Effet du niveau d'acidog'en'ecit'e de 2 concentr'es sur les performances zootechniques de ch'evres laiti'eres conduits au paaturage (Effect of Level of Acidogenecity in 2 Concentrates on Milk Performances of Grazing Dairy Goats). Rapport Station Exp'erimentale du Pradel DRSQ/PA., p. 6.

NRC. 2001. Nutrient Requirements of Dairy Cattle. National Academy Press, Washington, D.C., p. 341-353.

Pulina, G. A. Mazzette, G. Battacone and A. Nudda, 2006. Feed restriction alters milk production traits in Sarda dairy ewes. J. Dairy Sci. 89: 59.

Pridalova, H., B. Janstova, S. Cupakova, M. Drackova, P. Navratilova and L. Vorlova. 2009. Somatic cell count in goat milk. Folia Vet. 53: 101-105.

Robertson, J. B. and P. J. Vansoest. 1981. The detergent system of analysis and its application to human foods. In: W. P. James. and O. Theander (Ed.), The Analysis of Dietary Fiber in Food, Marcel Dekker, New York, N.Y., p. 123.

SPSS. 2006. Statistical Package for Social Sciences. PC version15. SPSS Inc. 444 N. Michigan Avenue Chicago, United States of America.

Singh, N. P. and S. Kumar. 2007. An Alternative Approach to Research for Harnessing

Production Potential of Goats, in Proceedings of Fourth National Extension Congress, JKVV, Jabalpur, March 9-11. p. 5-9.

Şekerden Ö. 2011. Factors affecting somatic cell counts and their relations with milk and milk constituent yield in Anatolian and F1 Anatolian x Italian crossbred buffaloes J. Anim. Prod. 52: 9-16.

TUIK. Turkish Statistical Institute. 2014. The Summary of Agricultural Statistics. Available from: http://www.turkstat.gov.tr.

Terzano, G. M, M. Mazzi, M. G. d'Elisi, F. P. Cuscunà, A. Borghese, P. Martiniello and C. Pacelli. 2007. Effect of intensive or extensive systems on buffalo heifers performances: Body measurements and respective indices. Ital. J. Anim. Sci. 6: 1237-1240. 